\title{
The feeding habits of the Southern elephant seal, Mirounga leonina, at Isla 25 de Mayo/King George Island, South Shetland Islands
}

\author{
G. A. Daneri - A. R. Carlini - E. R. Marschoff • \\ A. Harrington $\cdot$ J. Negrete $\cdot$ J. A. Mennucci $\cdot$ \\ M. E. I. Márquez
}

Received: 20 August 2014/Revised: 7 November 2014/Accepted: 19 November 2014/Published online: 18 December 2014

(c) Springer-Verlag Berlin Heidelberg 2014

\begin{abstract}
The Southern elephant seal (Mirounga leonina) is a major consumer from the Southern Ocean. This species is highly sexually dimorphic and frequently exhibits resource partitioning according to sex and/or age classes. This study analysed the feeding habits of the M. leonina population from Isla 25 de mayo (King George Island) in the spring/summer seasons of 1995/1996-2002/2003. A total of 232 individuals from different sex-age groups were stomach lavaged. The analysis of stomach samples showed that cephalopods were the main prey followed by fish, their frequency of occurrence being 98.1 and $17.9 \%$ respectively. Cephalopods were dominated by the Antarctic glacial squid, Psychroteuthis glacialis, which occurred in $83 \%$ of samples, constituting $57.2 \%$ in numbers and $61.3 \%$ in mass. Octopods were of lesser relevance, occurring in $18 \%$ of samples, but became more important in the diet of male individuals. Juvenile seals fed on a lower variety of cephalopod prey than older ones. This would coincide with the diving pattern characteristic of the different sex-age categories of seals. The predominance of
\end{abstract}

A. R. Carlini: Deceased on 20 December 2010.

Electronic supplementary material The online version of this article (doi:10.1007/s00300-014-1629-0) contains supplementary material, which is available to authorized users.

G. A. Daneri $(\bowtie) \cdot$ A. Harrington

División Mastozoología, Museo Argentino de Ciencias Naturales

"Bernardino Rivadavia", Avenida Angel Gallardo 470

(C1405DJR), Buenos Aires, Argentina

e-mail: gdaneri@macn.gov.ar; gadaneri@retina.ar

A. R. Carlini - E. R. Marschoff · J. Negrete ·

J. A. Mennucci · M. E. I. Márquez

Departamento de Biología de Predadores Tope, Instituto

Antártico Argentino, Cerrito 1248 (C1010AAZ), Buenos Aires,

Argentina
P. glacialis might be associated with the more southerly location of the foraging areas of this population compared to others. Fish were largely represented by the myctophid Gymnoscopelus nicholsi, which occurred in $81.3 \%$ of samples containing otoliths and constituted $76.4 \%$ in numbers and $66.4 \%$ in mass. However, while myctophids may be the dominant fish prey of elephant seals in areas close to the South Shetlands, they would be probably replaced by $P$. antarcticum as seals migrate towards higher latitudes.

Keywords Mirounga leonina - Diet · Cephalopods . Fish $\cdot$ South Shetlands · Antarctica

\section{Introduction}

Knowledge of diet is fundamental to studies of the ecology of pinnipeds and to the understanding of their role as consumers in marine ecosystems. The Southern elephant seal, Mirounga leonina, is an important apex predator that is widely distributed in the Southern Ocean. The main breeding concentrations of this phocid are located on subantarctic Islands, e.g., Souh Georgia, Heard, Kerguelen and Macquarie Islands. In contrast, the colony at Península Valdés, Argentina, is the only continental breeding site (Campagna and Lewis 1992; Reeves et al. 1992; McMahon et al. 2005; Authier et al. 2011). The total world population of M. leonina in the 1990s decade was estimated at over 660,000 individuals, with the breeding population at South Georgia producing almost $55 \%$ of the annual world pup production (Laws 1994; Boyd et al. 1996). This stock includes subpopulations at South Georgia Island, Islas Malvinas/Falkland Islands, South Orkney Islands, South Shetland Islands, South Sandwich Islands, Gough and 
Bouvet (McMahon et al. 2005; Carlini et al. 2006). The subpopulation of South Georgia has remained relatively stable since the 1950s. However the Isla 25 de Mayo/King George Island breeding population, has been declining since the 1990s to the present (SCAR 2006; Mennucci et al. 2012)

Food availability in the ocean has been suggested as a proximate cause in the changes in population numbers of different Southern elephant seal colonies (Green and Burton 1993; Hindell et al. 1994; McMahon et al. 2005, among others). Moreover, mass and energy reserves of seals coming ashore to breed, pup weaning mass, duration of foraging trips and juvenile survival may be linked to their dietary intake, which in turn depends on the temporal and spatial variation in the availability of food resources (Bester 1988; Slip 1995; Carlini et al. 1999; Piatkowski et al. 2002).

An assessment of the impact of elephant seals on prey resources in the Scotia Sea indicated that they account for nearly $75 \%$ of the $3.7 \times 10^{6}$ tonnes of cephalopods and $45 \%$ of the $2 \times 10^{6}$ tonnes of fish caught by seabirds and seals (Croxall et al. 1985). More recently, and specifically for the female component of the population of M. leonina from I. 25 de Mayo/KGI, Carlini et al. (2005) estimated, on a basis of 450 females, that the total biomass of fish and squid consumed by the breeding group, assuming a diet composed of $75 \%$ cephalopods and $25 \%$ fish, was $521 \mathrm{t}$ and $174 \mathrm{t}$ respectively during the post-breeding aquatic phase of the 1995/96 season.

The information on the feeding habits of this phocid species has markedly increased during the last decades. In general, studies come from South Georgia (Laws 1956; Rodhouse et al. 1992; Brown et al. 1999), South Orkney Islands (Clarke and MacLeod 1982), Prydz Bay (Green and Williams 1986), Heard and Macquarie Islands (Green and Burton 1993; Slip 1995; Bradshaw et al. 2003; Field et al. 2007; Newland et al. 2009, 2011, Walters et al. 2014), Browning Peninsula and Peterson Island (Van den Hoff et al. 2003) and Kerguelen Islands (Cherel et al. 2008; Chaigne et al. 2013). Specifically for the I. 25 de Mayo/KGI population, few mainly preliminary studies were performed (Daneri et al. 2000; Daneri and Carlini 2002; Piatkowski et al. 2002; Daneri et al. 2005). These studies have indicated that cephalopods and fish are common in the diet of $M$. leonina, the occurrence of crustaceans being occasional and of lesser importance. Furthermore, cephalopods and fish prey species identified to date were almost exclusively distributed to the south of the Antarctic Polar Front.

Thus, the aims of the present study were to examine the diet of the M. leonina colony from Stranger Point, 25 de $\mathrm{Mayo} / \mathrm{KGI}$, and to assess whether or not differences existed between the different components (sex-age categories) of the population.

\section{Materials and methods}

The sampling site is located along a coastal zone that stretches approximately $5 \mathrm{~km}$ from Potter Cove to Stranger Point, near the Argentine scientific station "Carlini" within the Antarctic Special Protected Area (ASPA) no. 132 $\left(62^{\circ} 15^{\prime} \mathrm{S}, 58^{\circ} 39^{\prime} \mathrm{W}\right)$ (Fig. 1). Throughout eight consecutive spring-summer seasons (1995/1996-2002/2003), a total of 232 Southern elephant seals were chemically immobilised by an intramuscular injection of either a combination of ketamine hydrochloride $(50 \mathrm{mg} / \mathrm{ml}$, estimated dose range: $3-6 \mathrm{mg} / \mathrm{kg})$ and xylazine hydrochloride $(20 \mathrm{mg} / \mathrm{ml}$, estimated dose range: $0.1-0.3 \mathrm{mg} / \mathrm{kg}$ ) or a mixture of $250 \mathrm{mg}$ tiletamine and $250 \mathrm{mg}$ zolazepam (dose range $0.8-1.2 \mathrm{mg} / \mathrm{kg}$ ). Daily checks were made along the beaches for recently hauled out seals of each sex-age category at the beginning of the molting season. Once anaesthetised, individuals were subjected to stomach lavage. When the duration of immobilisation of a given specimen allowed it, up to three lavages were performed. The diluted stomach contents were then sieved $(1.0 \mathrm{~mm}$ mesh) and the different prey taxa sorted. Furthermore, specimens were measured (standard length, with the animal in ventral recumbency, and axillary girth) and their weights were estimated (to calculate the actual dose given) using a published regression equation (Vergani and Spairani 1980).

Following the criteria of Laws (1956), Arnbom et al. (1992) and Rodhouse et al. (1992), i.e. a combination of standard length measurement and morphological features of the individuals studied, these were classified in four sexage categories:

(A) Juveniles regardless of sex $\leq 2$ years old.

(B) Sub- adult males of $\sim 3$ to 6 years old.

(C) Mature females $\geq 3$ years old.

(D) Adult males $\geq 7$ years old.

Individuals belonging to category A were not discriminated by sex since a number of studies have indicated that gender differences in foraging and/or diving behavior start, in general, from the second year of life onwards in both species of the genus Mirounga (Le Boeuf et al. 1996; Irvine et al. 2000; Field et al. 2005, among others).

Cephalopod lower beaks were identified by consulting the appropriate literature (Okutani and Clarke 1985; Clarke 1986; Xavier and Cherel 2009) and by comparison with reference collections housed at the Instituto Antártico Argentino and at the Museo Argentino de Ciencias Naturales "Bernardino Rivadavia". Lower rostral length (LRL) and lower hood length (LHL) of beaks were measured with vernier callipers to the nearest $0.01 \mathrm{~mm}$ for squid and octopus specimens respectively. Allometric equations used to estimate whole wet body mass and dorsal mantle length were taken from previous published literature (Clarke 
Fig. 1 Study area and its geographical location (modified from Carlini et al. 2006)

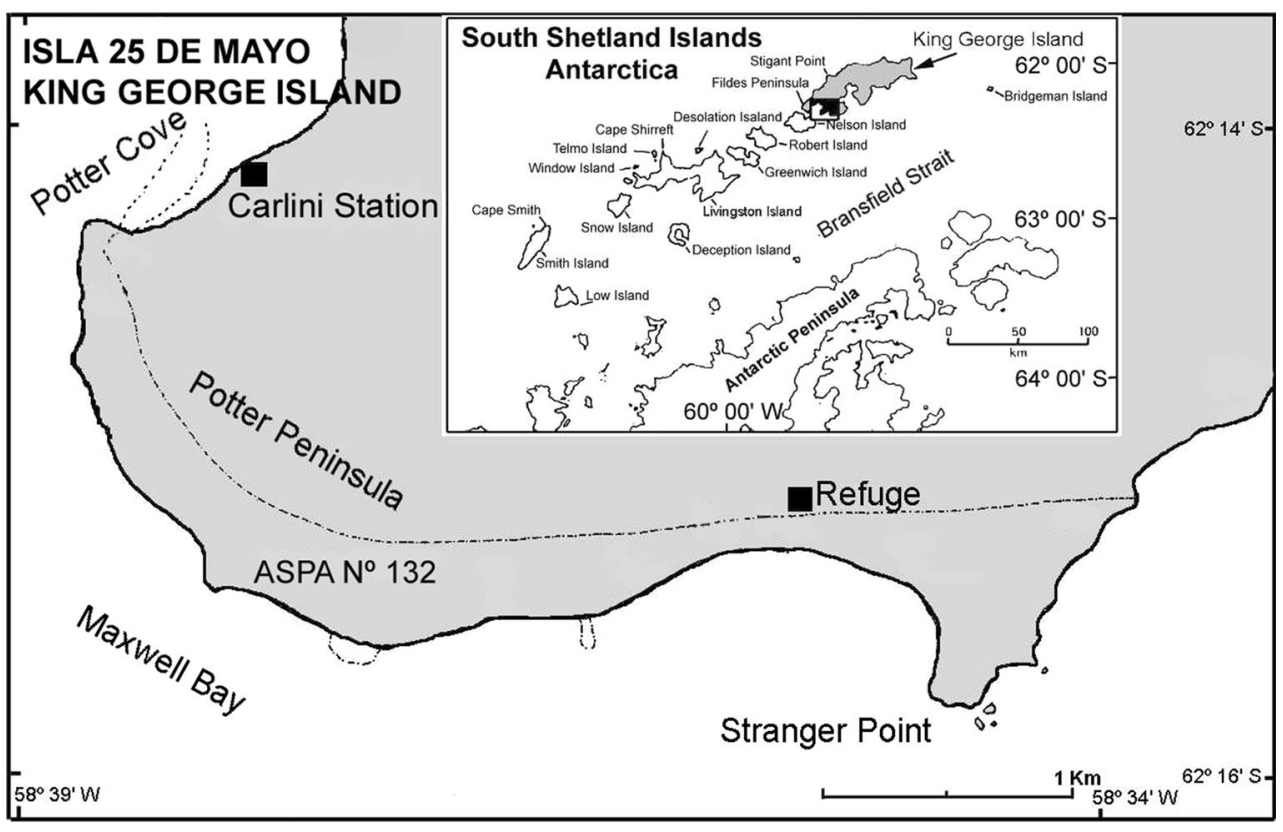

1986; Rodhouse et al. 1990; 1992; Groger et al. 2000; Xavier and Cherel 2009).

Fish sagittal otoliths were identified by comparison with reference collections and consultation of appropriate guides (Hecht 1987; Williams and McEldowney 1990; Reid 1996). Otoliths were assigned to three categories according to their level of erosion, and a correction factor was applied to compensate for this erosion, following Reid (1995). Fish length and mass were estimated from the corrected measurements of otolith length using regression equations (Williams and McEldowney 1990). Each fish has a pair of sagittal otoliths, and so, the fish mass estimated from the otoliths representing each species was divided by two, following North (1996). Otoliths markedly eroded or broken were not considered for identification and/or measurement. The relative importance of each prey taxon was evaluated (for cephalopods and fish separately) in terms of frequency of occurrence, numerical abundance and reconstituted mass. Also the index of relative importance (IRI) was estimated following Pinkas et al. (1971) but in a modified version where the original term by volume was replaced by percentage by wet weight (Reid 1995). In order to make the interpretation of the IRI easier, this index was expressed on a percent basis (\%IRI) following Cortés (1997).

The relationship between seal body length and the mean estimated mantle length of cephalopod prey in each stomach was examined by regression analysis. Additionally, a factorial correspondence analysis was performed in order to detect differential feeding patterns on cephalopod prey among the four sex-age categories of seals analysed. Finally, and exclusively for individuals of age $\geq 3$ years old, a log linear frequency test was performed in order to detect significant differences between sexes and seasons in the cephalopod diet composition.

\section{Results}

Overall diet

During the whole study period a total of 232 Southern elephant seals were sampled. Of these, $69.8 \%(n=162)$ presented prey remains, whereas the remainder $30.2 \%$ $(n=70)$ did not. Cephalopods occurred in $98.1 \%$ of stomachs containing food remains followed by fish $(17.9 \%)$ and crustaceans (12.1\%) (Table 1).

\section{Cephalopods}

This taxon was represented by a total of 3,225 beaks $(1,486$ upper; 1,739 lower) and in minor proportions by eye lenses, pens and only two buccal masses. Regarding exclusively those stomachs containing cephalopod remains $(n=159)$, the average number of lower beaks was 11 (range 1-214). The total number of species in any stomach ranged from 1 to 7 (mean =2). Eleven cephalopod taxa were identified. Of these, eight species corresponded to teuthoids. Octopods instead were represented by two species and one species group.

Overall, the dominant and most frequent cephalopod prey species was the Antarctic glacial squid, Psychroteuthis glacialis, followed by Slosarczykovia circumantarcti$c a$. These two taxa contributed together over $90 \%$ to the total Index of Relative Importance (Table 2). 
However, the taxonomical composition of the cephalopod prey of seals varied somewhat when these were discriminated by sex-age categories (Tables $3,4,5$ ).

The estimated size (mantle length) of the different cephalopod prey taxa taken by M. leonina discriminated by sex-age categories is given in Online Resource 1. The relationship between the lower rostral length of cephalopods taken and seal body length was examined for each prey taxon. A slightly positive $(r=0.27)$ but significant $(p<0.01)$ correlation was only found between $P$. glacialis size and elephant seal size.

On the other hand, the exploratory results obtained from the factorial correspondence analysis showed different patterns of relations between the cephalopod prey taxa and the different sex-age categories of seals (Fig. 2).

Table 1 Percentage frequency of occurrence $(\% F)$ of remains found in stomach contents of M. leonina at Isla 25 de Mayo/King George Island

\begin{tabular}{lr}
\hline Taxon & $\% F$ \\
\hline Cephalopods & 98.1 \\
\multicolumn{1}{c}{ Octopods } & 17.9 \\
$\quad$ Teuthoids & 92.0 \\
Fish & 17.9 \\
Gastropods & 1.2 \\
Bivalves & 2.5 \\
Crustaceans & 12.3 \\
Briozoans & 1.9 \\
Ascidians & 1.2 \\
Polychaetes & 0.6 \\
Nematodes & 100.0 \\
Acantocephales & 1.2 \\
Algae & 9.3 \\
No. of stomachs with prey remains & 162 \\
\hline
\end{tabular}

The first two axes accounted for almost $90 \%$ of the total inertia. The biplot of coordinates on these two axes showed:

1. A relation between adult male elephant seals (category D) and octopod prey.

2. A wide variety of cephalopod prey taxa, mainly teuthids, in relation to mature females (category C).

3. Immature juveniles (category A) and sub-adult males (category B) with a relatively similar pattern of relations with cephalopod prey, representing an intermediate diet between categories $\mathrm{C}$ and $\mathrm{D}$.

Finally, and regarding seals of both sexes of age $\geq 3$, the $\log$ linear frequency analysis showed significant differences between the sexes and seasons in the cephalopod diet of seals (Online Resource 2).

Fish

This prey taxon was present in $17.9 \%(n=29)$ of stomachs containing food remains (Table 1). These corresponded to two juveniles (category A), three subadult males (category B), 20 females (category C) and four adult males (category D). However, only $55 \%$ of these stomachs contained otoliths; the remainder presented a few eye lenses and/or bones. A total of 232 otoliths (198 sagittal, 34 lapillus) were removed, representing ten fish taxa of which seven were determined to the species level. The mean number of saggital otoliths removed from a given stomach was $12.4 \pm 25.2$ (range 1-105), whereas the minimum and maximum number of fish taxa found were one and three, respectively. The stomach that contained the maximum number of otoliths $(n=105)$ corresponded to an adult female with an estimated body weight of $703.9 \mathrm{~kg}$. Of these otoliths, 102 belonged to Gymnoscopelus nicholsi and the remaining 3 to Electrona antarctica, representing
Table 2 Taxonomical composition of the cephalopod prey of M. leonina, (all sex-age groups combined), expressed in terms of frequency of occurrence $(F, \% F)$, numerical abundance $(N, \% N)$, biomass (M grams, $\% M$ ) and index of relative importance (IRI, \%IRI)

\begin{tabular}{lrrrrrrrr}
\hline PREY taxon & $F$ & $\% F$ & $N$ & $\% N$ & $M$ & $\% M$ & IRI & $\%$ IRI \\
\hline Psychroteuthis glacialis & 132 & 83.0 & 994 & 57.2 & 85764.9 & 61.3 & 9836.8 & 82.0 \\
Gonatus antarcticus & 13 & 8.2 & 28 & 1.6 & 4800.1 & 3.4 & 41.2 & 0.3 \\
Moroteuthis knipovitchi & 5 & 3.1 & 8 & 0.5 & 2926.6 & 2.1 & 8.0 & 0.1 \\
Kondakovia longimana & 13 & 8.2 & 28 & 1.6 & 12769.1 & 9.1 & 87.8 & 0.7 \\
Alluroteuthis antarcticus & 32 & 20.1 & 67 & 3.9 & 22865.6 & 16.4 & 406.6 & 3.4 \\
Chiroteuthis veranyi & 1 & 0.6 & 1 & 0.1 & 114.9 & 0.1 & 0.1 & 0.0 \\
Slosarczykovia circumantarctica & 72 & 45.3 & 541 & 31.1 & 3737.3 & 2.7 & 1529.8 & 12.7 \\
Galiteuthis glacialis & 11 & 6.9 & 20 & 1.2 & 1181.7 & 0.8 & 13.8 & 0.1 \\
Papillated Pareledone spp. group & 18 & 11.3 & 23 & 1.3 & 2990.7 & 2.1 & 39.2 & 0.3 \\
Pareledone turqueti & 17 & 10.7 & 27 & 1.6 & 2596.0 & 1.9 & 36.4 & 0.3 \\
Adelieledone polymorpha & 2 & 1.3 & 2 & 0.1 & 97.5 & 0.1 & 0.2 & 0.0 \\
Total & 159 & & 1739 & 100 & 139844.3 & 100 & 12000.0 & 100 \\
\hline
\end{tabular}


Table 3 Taxonomical composition of the cephalopod prey of $M$. leonina expressed in terms of percent frequency of occurrence

\begin{tabular}{lrrrr}
\hline Prey taxon & \multicolumn{5}{l}{ Sex-age class } & & \\
\cline { 2 - 5 } & Juv & \multicolumn{1}{c}{ SA } & \multicolumn{1}{c}{$F$} & \multicolumn{1}{c}{$M$} \\
\hline Psychroteuthis glacialis & 63.2 & 78.4 & 88.2 & 75.0 \\
Gonatus antarcticus & 5.3 & 5.4 & 10.8 & 0.0 \\
Moroteuthis knipovitchi & 0.0 & 2.7 & 3.2 & 8.3 \\
Kondakovia longimana & 0.0 & 2.7 & 11.8 & 8.3 \\
Alluroteuthis antarcticus & 0.0 & 18.9 & 20.4 & 8.3 \\
Chiroteuthis veranyi & 0.0 & 0.0 & 1.1 & 0.0 \\
Slosarczykovia circumantarctica & 47.4 & 27.0 & 52.7 & 8.3 \\
Galiteuthis glacialis & 0.0 & 8.1 & 8.6 & 8.3 \\
Papillated Pareledone spp. group & 15.8 & 21.6 & 5.4 & 25.0 \\
Pareledone turqueti & 5.3 & 16.2 & 7.5 & 33.3 \\
Adelieledone polymorpha & 0.0 & 2.7 & 0.0 & 8.3 \\
\hline Juv Jun & & & & \\
& & &
\end{tabular}

Juv Juveniles regardless of sex $\leq 2$ years old; $S A$ sub-adult males $\sim 3$ to 6 years old; $F$ mature females $\geq 3$ years old; $M$ adult males $\geq 7$ years old

Table 4 Taxonomical composition of the cephalopod prey of $M$. leonina expressed as a percentage of the total number of beaks

\begin{tabular}{|c|c|c|c|c|}
\hline \multirow[t]{2}{*}{ Prey taxon } & \multicolumn{4}{|c|}{ Sex-age class } \\
\hline & Juv & $S A$ & $\mathrm{~F}$ & $\mathrm{M}$ \\
\hline Psychroteuthis glacialis & 57.7 & 59.8 & 56.9 & 50.0 \\
\hline Gonatus antarcticus & 3.8 & 1.7 & 1.6 & 0.0 \\
\hline Moroteuthis knipovitchi & 0.0 & 0.9 & 0.4 & 2.5 \\
\hline Kondakovia longimana & 0.0 & 0.4 & 1.8 & 2.5 \\
\hline Alluroteuthis antarcticus & 0.0 & 5.7 & 3.7 & 2.5 \\
\hline Chiroteuthis veranyi & 0.0 & 0.0 & 0.1 & 0.0 \\
\hline Slosarczykovia circumantarctica & 30.8 & 19.2 & 33.4 & 20.0 \\
\hline Galiteuthis glacialis & 0.0 & 1.7 & 1.1 & 2.5 \\
\hline Papillated Pareledone spp. group & 5.8 & 4.8 & 0.4 & 7.5 \\
\hline Pareledone turqueti & 1.9 & 5.2 & 0.7 & 10.0 \\
\hline Adelieledone polymorpha & 0.0 & 0.4 & 0.0 & 2.5 \\
\hline Total no. of lower beaks & 52 & 229 & 1,418 & 40 \\
\hline
\end{tabular}

$J u v$ Juveniles regardless of sex $\leq 2$ years old; $S A$ sub-adult males $\sim 3$ to 6 years old; $F$ mature females $\geq 3$ years old; $M$ adult males $\geq 7$ years old

an estimated biomass of 1722.2 and $31.6 \mathrm{~g}$, respectively. The predominant fish prey species was the myctophid $G$. nicholsi, which presented the greatest \% IRI (over $90 \%$ ). In terms of occurrence and numbers, the nototheniid Pleuragramma antarcticum was second in importance, whereas Gobionotothen gibberiffrons was the second contributor in mass $(13.1 \%)$ (Table 6).

However, the taxonomical composition of the fish prey discriminated by gender indicated a lower presence of $G$. nicholsi coupled with a proportionally greater contribution
Table 5 Taxonomical composition of the cephalopod prey of $M$. leonina expressed as a percentage of the total estimated biomass

\begin{tabular}{lrrrrr}
\hline Prey taxon & \multicolumn{3}{l}{ Sex-age class } & & \\
\cline { 2 - 6 } & Juv & SA & F & \multicolumn{2}{c}{ M } \\
\hline Psychroteuthis glacialis & 72.5 & 55.5 & 64.0 & 39.1 \\
Gonatus antarcticus & 10.1 & 2.5 & 3.8 & 0.0 \\
Moroteuthis knipovitchi & 0.0 & 2.6 & 1.9 & 4.4 \\
Kondakovia longimana & 0.0 & 0.3 & 9.1 & 35.3 \\
Alluroteuthis antarcticus & 0.0 & 25.5 & 15.8 & 2.8 \\
Chiroteuthis veranyi & 0.0 & 0.0 & 0.1 & 0.0 \\
Slosarczykovia & 4.9 & 1.4 & 3.0 & 0.6 \\
$\quad$ circumantarctica & & & & \\
Galiteuthis glacialis & 0.0 & 1.1 & 0.8 & 0.7 \\
Papillated Pareledone spp. & 5.1 & 7.8 & 0.3 & 10.1 \\
$\quad$ group & & & & \\
Pareledone turqueti & 7.3 & 3.0 & 1.2 & 6.5 \\
Adelieledone polymorpha & 0.0 & 0.3 & 0.0 & 0.3 \\
Total (kg) & 2059.2 & 21604.0 & 108010.9 & 8170.2 \\
\hline
\end{tabular}

Juv Juveniles regardless of sex $\leq 2$ years; $S A$ sub-adult males $\sim 3$ to 6 years old; $F$ mature females $\geq 3$ years old; $M$ Adult males $\geq 7$ years old

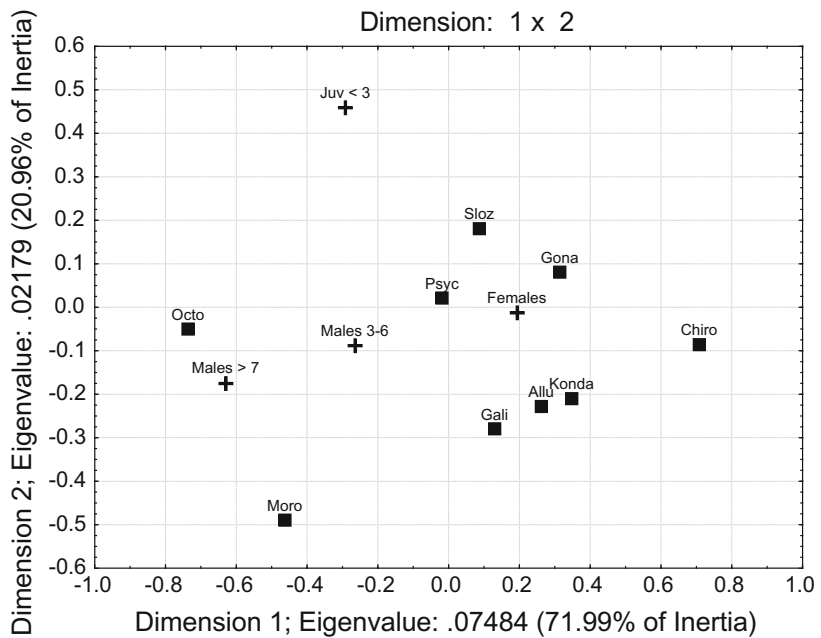

Fig. 2 Two-dimensional plot of the row and column coordinates showing the spatial distribution of the different sex-age categories of seals and their cephalopod prey taxa. Filled square box Prey taxon, Plus sex-age category. Sloz: Slozarksikovia circumantarctica, Psyc: Psychroteuthis glacialis, Gona: Gonatus antarcticus, Gali: Galiteuthis glacialis, Allu: Alluroteuthis antarcticus, Kond: Kondakovia longimana, Moro: Moroteuthis knipovitchi Chiro: Chiroteuthis veranyi, Octo: octopodid spp.

of $G$. gibberifrons in the diet of males. Furthermore $G$. nicholsi had a higher \%IRI in the diet of females in comparison to that of males (94.8 vs. $55.9 \%$ ) (Table 6).

The estimated size of the fish ingested (regarding all fish taxa identified) ranged from $73.5 \mathrm{~mm}$ (E. antarctica) to $292.1 \mathrm{~mm}$ (Chionodraco myersi). The estimated mean 
Table 6 Taxonomical composition of the fish prey of Southern elephant seals at Isla 25 de Mayo/King George Island, in terms of frequency of occurrence $(\% F)$, numbers $(\% N)$, biomass $(\% M)$ and index of relative importance (\% IRI)

\begin{tabular}{|c|c|c|c|c|c|c|c|c|c|c|c|c|}
\hline \multirow[t]{2}{*}{ Taxon } & \multicolumn{4}{|c|}{ Sexes combined } & \multicolumn{4}{|c|}{ Females } & \multicolumn{4}{|c|}{ Males } \\
\hline & $\% F$ & $\% N$ & $\% M$ & $\%$ IRI & $\% F$ & $\% N$ & $\% M$ & $\%$ IRI & $\% F$ & $\% N$ & $\% M$ & $\%$ IRI \\
\hline \multicolumn{13}{|l|}{ Myctophidae } \\
\hline Gymnoscopelus nicholsi & 81.3 & 74.2 & 66.4 & 93.0 & 90.9 & 78.8 & 76.8 & 95.1 & 60.0 & 31.6 & 19.1 & 55.9 \\
\hline Electrona antarctica & 25.0 & 4.5 & 1.1 & 1.1 & 27.3 & 3.4 & 0.9 & 0.8 & 20.0 & 15.8 & 2.2 & 6.6 \\
\hline Indet. Myctophidae & 18.8 & 4.0 & - & - & 18.2 & 3.4 & - & - & 9.1 & 10.5 & - & - \\
\hline \multicolumn{13}{|l|}{ Nototheniidae } \\
\hline Pleuragramma antarcticum & 25.0 & 9.0 & 5.5 & 2.9 & 27.3 & 8.4 & 5.3 & 2.5 & 9.1 & 10.5 & 6.4 & 2.8 \\
\hline Gobionotothen gibberifrons & 12.5 & 3.0 & 13.1 & 1.6 & & & & & 18.2 & 31.6 & 72.3 & 34.7 \\
\hline Indet. Nototheniidae & 18.2 & 1.0 & - & - & 18.2 & 1.1 & - & - & - & - & - & - \\
\hline \multicolumn{13}{|l|}{ Channichthyidae } \\
\hline Chionodraco rastrospinosus & 12.5 & 1.5 & 5.8 & 0.7 & 18.2 & 1.7 & 7.0 & 1.1 & - & - & - & - \\
\hline Chionodraco myersi & 6.3 & 1.5 & 7.3 & 0.4 & 9.1 & 1.7 & 8.9 & 0.6 & - & - & - & - \\
\hline Dacodraco hunteri & 6.3 & 0.5 & 0.9 & 0.1 & 9.1 & 0.6 & 1.1 & 0.1 & - & - & - & - \\
\hline Indet. Channichthyidae & 6.3 & 1.0 & - & - & 9.1 & 1.1 & - & - & - & - & - & - \\
\hline Total number of otoliths & & 198 & & & & & & & & & & \\
\hline
\end{tabular}

standard length of $G$. nicholsi was $139.3 \mathrm{~mm} \pm 12.2$ (range 95.3-168.8 mm) corresponding to specimens of 9.7-59.1 g wet mass. On the other hand, the estimated mean standard length of $P$. antarcticum was $132.7 \mathrm{~mm} \pm 44.3$ (range 90.7-226.2 $\mathrm{mm}$ ) representing specimens of $5.0-92.8 \mathrm{~g}$ wet mass. The size frequency distributions of these two fish taxa indicated that the modal length class of $G$. nicholsi (150-155 mm) was remarkably higher than that of $P$. antarcticum (100-110 mm) although the latter presents a second smaller peak between 170 and $180 \mathrm{~mm}$ (Fig. 3).

\section{Crustaceans}

These were present in $12.4 \%(n=22)$ of the 162 stomachs containing food remains (Table 1). Most of them were represented by exoskeletal and appendage fragments. Their identification indicated that amphipods occurred in all stomachs containing crustacean remains; isopods and decapods (Natantia) occurred in one stomach each and euphausids in two.

\section{Discussion}

The relative importance of the two main components found in the diet of $M$. leonina, i.e. cephalopods and fish, is influenced by two important factors:

1. The distance between foraging grounds and their breeding and/or moulting sites. Both male and female elephant seals may travel great distances, e.g. over $3,000 \mathrm{~km}$, from land to foraging areas (McConnell and Fedak 1996; Jonker and Bester 1998; Biuw et al. 2007; Dragon et al. 2012). Specifically for Isla 25 de Mayo/King George Island elephant seals, Bornemann et al. (2000) and Tosh et al. (2009) reported feeding trips of over $1,500 \mathrm{~km}$ for both juveniles and adults of both sexes and that a considerable number of the tracked individuals had focussed their foraging activities in areas located along the west and east shelf margin of the Antarctic Peninsula, also reaching the South Orkneys and South Georgia.

2. The relative contributions of cephalopods and fish to the diet of seals are influenced by the rate of passage of digesta through their alimentary tract. Bigg and Fawcett (1985) concluded that hard parts of squid such as chitinous beaks are resistant to digestion and may be retained in the stomach rugae or the pyloric sphincter of the otariid Callorhinus ursinus as a result of their irregular shape, while fish bones and otoliths are readily digested and pass more rapidly into the intestine. In support of this, Harvey and Antonelis (1994) reported that beaks often remained in the stomachs of captive northern elephant seals after repeated lavages, some of which were recovered up to 9 days after ingestion. In contrast, relatively undigested otoliths were collected only if lavage samples were performed within $24 \mathrm{~h}$ of feeding. Moreover, Tollit et al. (1997), based on experimental feeding trials with captive specimens of Phoca vitulina, reported that hard remains, such as cephalopod beaks, could be recovered up to 

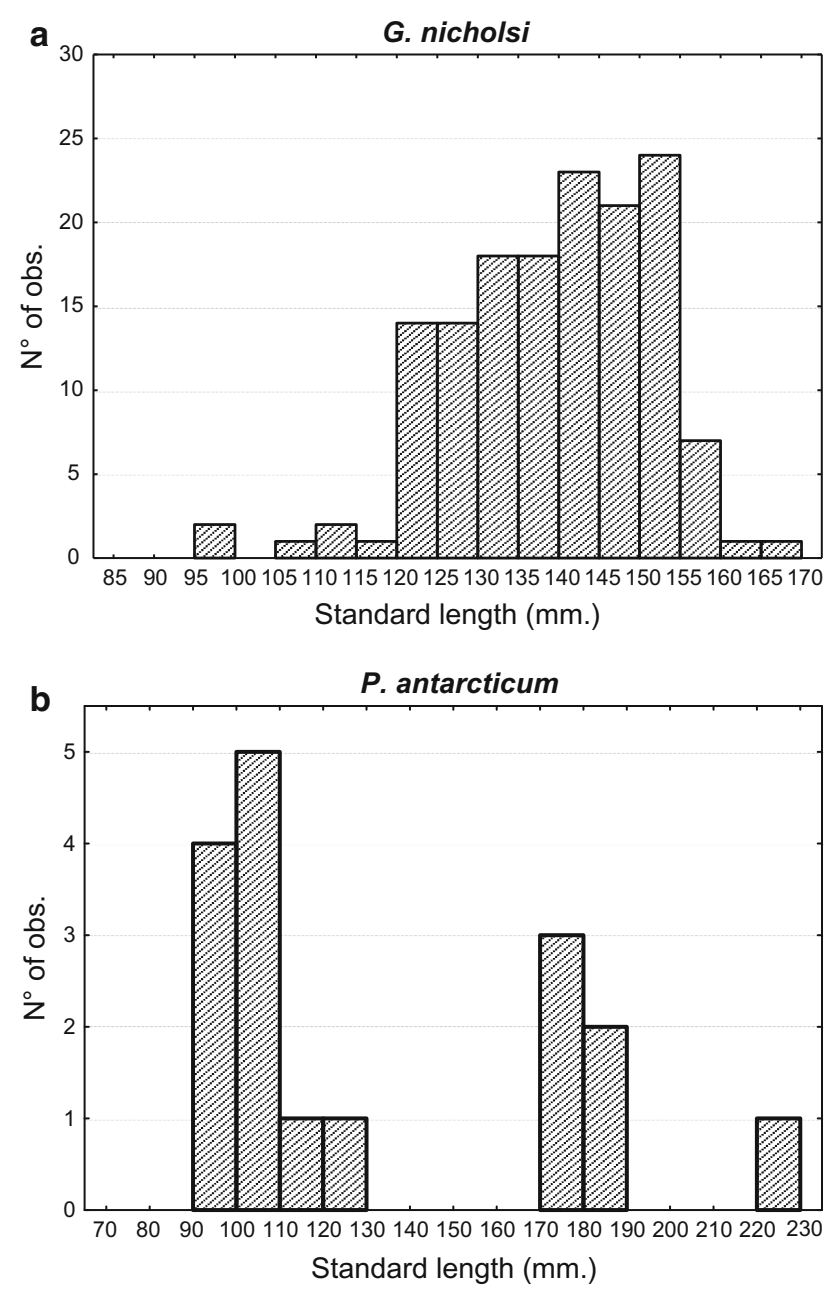

Fig. 3 The estimated standard length frequency distribution of a $G$. nicholsi and $\mathbf{b}$ P. antarcticum preyed upon by M. leonina from Isla 25 de Mayo/King George Island

7 days after ingestion. Taking into consideration all these potential biases inherent to the stomach lavage method, we assumed for M. leonina

(a) a similar retention time of hard remains in stomachs to those reported for $P$. vitulina and $M$. angustirostris.

(b) a mean speed of displacement at sea of $50 \mathrm{~km} /$ day according to data reported from satellite tracked elephant seal individuals from Stranger Point (Bornemann et al. 2000; Tosh et al. 2009).

Thus, the different prey taxa recovered from stomach lavages in this study might well have represented cephalopod and fish prey ingested at distances of ca. 350 and $50 \mathrm{~km}$,respectively, from the sampling site.

\section{Cephalopods}

Overall, the cephalopod portion of the diet of M. leonina, regarding all sex-age categories of seals combined, was largely represented by the Antarctic glacial squid, $P$. glacialis (Table 2). Moreover, this same squid species was dominant in each one of the seal categories considered (Tables 3, 4, 5).

In terms of frequency of occurrence, only four cephalopod taxa (excluding $P$. glacialis) were present in at least $10 \%$ of elephant seals sampled: the teuthoids S. circumantarctica and A. antarcticus and the octopods $P$. turqueti and the papillated Pareledone species group.

It is worth emphasizing at this point that, until recently, all papillated octopod specimens of Pareledone from the Antarctic Peninsula area were ascribed to the species Pareledone charcoti. However, a re-examination of the papillated-type material of Pareledone has led to the identification of eight new species of papillated Pareledone from the Antarctic Peninsula region (Allcock 2005; Allcock et al. 2007). These are distinguished by subtle taxonomic characters, such as the morphology and placement of their papillae, whereas traditional features such as beak morphology fail to separate them as they all show a strong resemblance to $P$. charcoti (Allcock 2005; Daneri et al. 2012).

The clear dominance of $P$. glacialis as a cephalopod prey of elephant seals from Stranger Point constituted a distinctive feature in comparison with previous dietary reports of M. leonina, based on stomach content analyses, at other localities of the Southern Ocean (Table 7). The only exception was a study performed at Vincennes Bay, East Antarctica, where P. glacialis was also a dominant prey of mostly subadult male seals (Van den Hoff et al. 2003). Unlike our findings, the relatively few trophic studies of M. leonina based on stable isotope techniques (Cherel et al. 2008; Ducatez et al. 2008; Newland et al. 2011; Walters et al. 2014) or fatty acid signature analysis (Brown et al. 1999; Newland et al. 2009) at different localities of the Southern Ocean have not shown P. glacialis (not even teuthids) to be an important prey (or potential prey) of Southern elephant seals.

Another distinctive feature observed in the present study was the minor diversity of squid prey taxa at this colony in comparison with those located at lower latitudes of the Southern Ocean (e.g. Heard, Macquarie, Kerguelen, South Georgia). Moreover, coinciding with Van den Hoff et al.'s (2003) observation, it may be stated that the farther south the colony of elephant seals is located, the less the diversity of squid prey species observed in their diet (Fig. 4). This might be explained, at least partially, because the more northerly Southern elephant seal colonies are located at the latitude of (or proximate to) the Antarctic Polar Front. This oceanic area represents a natural barrier between distinct biological communities. Although this front is mobile and rich in eddies and loops that span a zone as wide as $150 \mathrm{~km}$, it has a fairly constant mean position from year to 
Table 7 The differential contribution of the Antarctic glacial squid Psychroteuthis glacialis to the diet of M. leonina at different localities of the Southern Ocean expressed in terms of frequency of occurrence $(\% F)$, numbers $(\% N)$ and biomass $(\% M)$

\begin{tabular}{lllllllll}
\hline & $\begin{array}{l}\text { 25 de Mayo/King } \\
\text { George (1) }\end{array}$ & $\begin{array}{l}\text { South Orkneys } \\
(2)\end{array}$ & $\begin{array}{l}\text { South Georgia } \\
(3)\end{array}$ & $\begin{array}{l}\text { Heard } \\
(4)\end{array}$ & $\begin{array}{l}\text { Macquarie } \\
(4)\end{array}$ & $\begin{array}{l}\text { Heard } \\
(5)\end{array}$ & $\begin{array}{l}\text { Macquarie } \\
(6)\end{array}$ & $\begin{array}{l}\text { Vincennes } \\
\text { Bay (7) }\end{array}$ \\
\hline$\% F$ & 83.0 & 54.5 & 80.0 & 30.5 & 9.2 & 39.0 & 34.5 & 75.0 \\
$\% N$ & 57.2 & 26.0 & 33.7 & 12.8 & 0.8 & 21.0 & 2.9 & 81.8 \\
$\% M$ & 61.4 & 8.7 & 15.4 & 7.7 & 0.7 & 5.2 & - & 21.1 \\
\hline
\end{tabular}

(1) Present study, (2) Clarke and MacLeod (1982), (3) Rodhouse et al. (1992), (4) Green and Burton (1993), (5) Slip (1995), (6) Field et al. (2007), (7) Van den Hoff et al. (2003)

year located at ca. $55^{\circ} \mathrm{S}$ (Fischer and Hureau 1988; Moore et al. 1999). Thus, the more northern M. leonina colonies (e.g. South Georgia, Macquarie, Heard, Kerguelen, Marion) may have access to a wider diversity of prey taxa (i.e. sub-Antarctic/Antarctic taxa), which occur either to the north or south of this front. This is reinforced by information obtained from studies on the foraging ecology of $M$. leonina, which indicated that the movements at sea and potential feeding grounds of individuals from the more northerly breeding colonies are not confined to the south of the Antarctic Polar front, but are also within its bounds and to the north of it (Slip et al. 1994; McConnell and Fedak 1996; Field et al. 2001, 2005; Biuw et al. 2007; Cherel et al. 2008; Ducatez et al. 2008; McIntyre et al. 2011).

Specifically for the colony of M. leonina from Isla 25 de mayo/King George, Bornemann et al. (2000) tracked 13 post-moult adult females and 7 weaned pups fitted with satellite transmitters.

Some females stayed in a localised area between the South Shetlands and the South Orkneys, while others showed remarkably similar tracks along the shelf margin

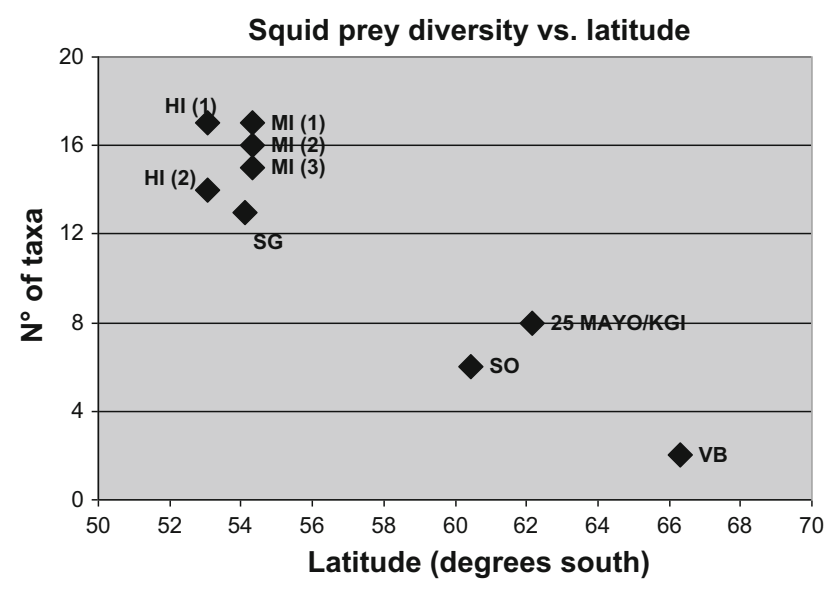

Fig. 4 Comparison of the number of squid prey taxa recovered from stomachs of M. leonina at different localities of the Southern Ocean, HI Heard Island (1) Green and Burton (1993) (2) Slip (1995), MI Macquarie Island (1) Green and Burton (1993) (2) Van den Hoff (2004) (3) Field et al. (2007), SG South Georgia (Rodhouse et al. 1992), 25 M/KGI Isla 25 de Mayo/King George Island (this study), $V B$ Vincennes Bay (Van den Hoff et al. 2003) west of the Antarctic Peninsula, moving as far as $90^{\circ} \mathrm{W}$ up to the Bellinghausen Sea. In contrast, juveniles moved south-westward into the Pacific sector of the Southern Ocean and centred their foraging activities in ice-free waters west of the De Gerlache Seamounts. For this same colony, Tosh et al. (2009) instrumented 15 adult males with satellite-linked depth recorders before initiating their postmoulting aquatic phase. Some males remained within 500 $\mathrm{km}$ of the island focussing movements in the Bransfield Strait and around the Antarctic Peninsula. Interestingly, three males moved along the shelf margin east of the Peninsula, reaching their southernmost positions in the interior pack ice of the Weddell Sea as far as $75^{\circ} \mathrm{S}$.

In brief, the aforementioned studies indicated that elephant seal individuals of different sex-age classes from the colony of Stranger Point focussed their foraging activities in areas located definitively to the south of the Antarctic Polar Front. Coincidentally, these are also areas where the squid $P$. glacialis is highly abundant.

A comparative analysis of the size of the different cephalopod prey taxa ingested by seals and the maximum size that individuals from each of these taxa may reach in the wild indicates that $M$. leonina preyed upon relatively small or medium representatives of their respective species (Online Resource 3). Similar findings were reported in previous dietary studies performed at South Georgia and Heard Island (Rodhouse et al. 1992; Slip 1995).

When analysing specifically the cephalopod diet of elephant seals from Stranger Point, some distinctive features can be observed: (1) a lesser diversity of prey species in the diet of juvenile seals in comparison with older individuals, (2) the occurrence of large muscular pelagic teuthid species (e.g. M. knipovitchi, K. longimana) in the diet of seals of age $\geq 3$ years old, and (c) a greater contribution of octopods to the diet of males, which gradually increases from subadults to adults (Tables 3, 4, 5; Fig. 2).

The minor diversity of prey species caught by immature seals ( $<3$ years old) might be explained by a lesser diving ability than older ones. In fact, previous studies on the diving behaviour of Weddell seals, Leptonychotes weddellii, and Northern elephant seals, Mirounga angustirostris, have indicated that juveniles perform shorter and shallower dives than 
adults (Kooyman et al. 1983; Burns 1999). In particular, the diving skills of juvenile northern elephant seals increased with time and experience up to 2 years of age when modal diving performance equaled that of adults (Le Boeuf et al. 1996). Specifically for M. leonina, Irvine et al. (2000) reported that juveniles of up to 12 months old at Macquarie Island had less diving ability with respect to the duration and depth than adults of the same colony, thus restricting their foraging ability (e.g. the capability of seals to capture vertically moving prey). The reduced vertical depth range within which juveniles forage could explain the lower diversity of cephalopod prey taxa found in this study. Reinforcing this hypothesis, ontogenetic shifts in bathymetric distribution have been reported in many oceanic squid species (e.g. P. glacialis, G. glacialis, G. antarcticus and $A$. antarcticus, among others) with juvenile individuals living at shallow depths and adults found deeper (Lu and Williams 1994; Filippova and Pakhomov 1994; Groger et al. 2000; Collins and Rodhouse 2006). This is in line with our findings that showed a smaller size of squid prey species captured by immature seals (age $\leq 2$, category A) in comparison with those caught by other sex-age classes (Online Resource 1). Furthermore, the occurrence of octopods in their diet, though not relevant, might be explained by the eurybathic distribution of the members of the genus Pareledone, (from eulittoral to over 1,000 m depth) (Collins and Rodhouse 2006; Allcock et al. 2011), thus falling within the relatively restricted vertical foraging range of young seals. On the other hand, the greater contribution of octopods to the diet of subadult and adult males (Tables 3, 4 5) might be a consequence of intersexual differences in the diving patterns of seals. In support of this hypothesis, Hindell et al. (1991) and Slip et al. (1994) indicated, for Macquarie Island elephant seals, that there were two characteristic types of dive performed by the specimens studied. Type 1 dives, which were interpreted as pelagic foraging dives and were mainly undertaken by females, and type 2 dives, which were considered as benthic foraging dives and were common in males but rarely seen in females. If the diving patterns for the Isla 25 de Mayo/King George Island population were similar, it would be more likely that males would forage on the bottom and prey on benthic octopods than females.

Fish

This prey taxon was present in $17.9 \%$ of the seal stomachs containing food remains throughout the whole study period (range through years 5.6-23.5) (Table 1). The taxonomical composition of the fish component showed a clear dominance of the Family Myctophidae, mainly represented by G. nicholsi, which occurred in over $80 \%$ of stomachs containing otoliths $(n=16)$ and constituted $75 \%$ in numbers of fish consumed (Table 6). Most of the background information on the fish prey of M. leonina is relatively scarce and comes mainly from stomach content analyses, either from dead or live individuals previously anaesthesised and then subjected to stomach lavage at different localities of its distributional range (Laws 1956; Green and Burton 1993; Slip 1995; Daneri and Carlini 2002; Field et al. 2007). These studies have shown the differential contribution of myctophids to the fish portion of the diet of M. leonina, at least in terms of numerical abundance, at most of the localities studied (Table 8). More recent studies on the trophic ecology of M. leonina based on stable isotopes analysis also suggested that myctophids might constitute an important food resource of seals at least during certain periods of their aquatic phase (Cherel et al. 2008; Ducatez et al. 2008; Newland et al. 2011). Additionally, a number of dietary studies of this phocid species based on fatty acid signature analysis have drawn similar conclusions (Brown et al. 1999; Bradshaw et al. 2003; Newland et al. 2009). Moreover, a study on the foraging ecology of Southern elephant seals equipped with Time-Depth-Recorders that also included light sensors suggested that at least one part of bioluminescence events
Table 8 Taxonomical composition at the family level of the fish component in the diet of M. leonina at different localities of the Southern Ocean

(1) Green and Burton (1993), (2) Slip (1995), (3) Field et al. 2007 (4) Daneri and Carlini (2002), (5) present study

\begin{tabular}{lrrrccc}
\hline Family & $\begin{array}{l}\text { Heard } \\
(1)\end{array}$ & $\begin{array}{l}\text { Heard } \\
(2)\end{array}$ & $\begin{array}{l}\text { Macquarie } \\
(1)\end{array}$ & $\begin{array}{l}\text { Macquarie } \\
(3)\end{array}$ & $\begin{array}{l}\text { 25 de Mayo/KGI } \\
(4)\end{array}$ & $\begin{array}{l}\text { 25 de Mayo/KGI } \\
(5)\end{array}$ \\
\hline Myctophidae & 59.3 & 77.7 & 87.8 & 93.3 & 80.4 & 82.4 \\
Nototheniidae & 31.4 & 22.3 & 0.0 & 3.6 & 17.4 & 13.1 \\
Channichthyidae & 9.3 & 0.0 & 0.0 & 0.0 & 2.2 & 4.5 \\
Centrolophidae & 0.0 & 0.0 & 0.0 & 1.3 & 0.0 & 0.0 \\
Gempylidae & 0.0 & 0.0 & 0.0 & 0.3 & 0.0 & 0.0 \\
Paralepididae & 0.0 & 0.0 & 0.0 & 0.8 & 0.0 & 0.0 \\
Phosichthyidae & 0.0 & 0.0 & 0.0 & 0.3 & 0.0 & 0.0 \\
Psychrolutidae & 0.0 & 0.0 & 0.0 & 0.3 & 0.0 & 0.0 \\
Bathylagidae & 0.0 & 0.0 & 12.2 & 0.3 & 0.0 & 0.0 \\
Total & 100.0 & 100.0 & 100.0 & 100.0 & 100.0 & 100.0 \\
\hline
\end{tabular}


detected were emitted by myctophid fish (Vacquié-Garcia et al. 2012).

Although channichthyids were absent in the diet of males, a previous report on the fish prey of M. leonina from this same colony showed the occurrence of Chionodraco sp. and Pagetopsis sp. otoliths in stomach contents of juvenile males (Daneri and Carlini 2002).

Regarding the habitat and distribution of the main fish prey taxa identified in this study, G. nicholsi and E. antarctica are two of the most common and abundant myctophids south of the Antarctic Polar Front (Gon and Heemstra 1990). They occur commonly in epi- and mesopelagic waters over continental shelves and oceanic waters of the Southern Ocean (Williams and McEldowney 1990; Barrera-Oro 2002). On the other hand, the most representative prey species of the Family Nototheniidae was the Antarctic silverfish $P$. antarcticum, the only nototheniid that leads an entirely pelagic existence. It is usually abundant over the continental shelf, especially in higher latitudes. Larvae and juveniles commonly occur in the upper $100 \mathrm{~m}$ of the water column, whereas adults tend to occur near the bottom over the shelf and oceanic waters to depths below 400 m (Hubold and Ekau 1987; Williams and McEldowney 1990). The other nototheniid, G. gibberifrons, is a typical benthic species that also occurs over shelf waters mainly around islands of the Scotia Arc and northern tip of Antarctic Peninsula (depth range 5-700 m) (Gon and Heemstra 1990). The channichthyid fish species identified are benthopelagic and have a circumantarctic distribution on the continental shelf at depths from close to the surface (juveniles) to depths nearly $1,000 \mathrm{~m}$ (Fischer and Hureau 1988; Williams and McEldowney 1990). Thus, the comparative analysis of the fish composition of the diet of seals between sexes would also indicate an alternation of benthic and pelagic foraging in males and a predominantly pelagic foraging pattern in females as suggested by Hindell et al. (1991) and Slip et al. (1994).

In relation to the fish size classes predated by seals, $G$. nicholsi and $P$. antarcticum attain sexual maturity at 160-180 mm and ca. $140 \mathrm{~mm}$, respectively (Hubold 1984; Gon and Heemstra 1990). The estimated sizes of these two species from the corrected otolith lengths indicated that $M$. leonina preyed mainly upon immature stages of G. nicholsi and both immature and mature P. antarcticum (Fig. 3).

Myctophids are widely distributed in the Southern Ocean and largely widespread from the Antarctic Polar Frontal Zone to the edge of the Antarctic continental slope, reaching latitudes of up to $65^{\circ} \mathrm{S}$ and sometimes even further south (Kozlov 1995). Moreover, a study of the community structure of mesopelagic fishes in the slope waters of Isla 25 de Mayo/King George indicated that the family Myctophidae was the most important in specific diversity, numerical abundance and wet weight (Pusch et al. 2004). However, as was previously stated, foraging areas of the different components of this elephant seal population are predominantly located to the south of the Antarctic Polar Front and over the Antarctic continental shelf (Bornemann et al. 2000; Tosh et al. 2009). Therefore, it is highly probable that while myctophids may be the dominant fish prey of Southern elephant seals in areas close to Isla 25 de Mayo/King George Island, these are probably replaced by $P$. antarcticum, as seals migrate southward towards higher latitudes.

Interestingly, none of the main fish and cephalopod prey taxa of M. leonina identified in the present study were the target of commercial fisheries in the South Atlantic sector of the Southern Ocean during the study period (CCAMLR 2008). However, the eventual establishment of a commercial fishery for the Antarctic glacial squid $P$. glacialis, a species having good-quality flesh that makes it a potentially valuable commercial resource (Fischer and Hureau 1988), may have negative consequences upon the elephant seal population from Stranger Point since this squid species apparently constitutes one of its most important food items.

Therefore, monitoring the diet of the different sex-age categories of elephant seals from this colony for a longer period of time (preferentially a decade) will be essential to gain an adequate knowledge of their trophodynamics and, in turn, of the ecological role of this phocid species as a top predator of the Antarctic marine ecosystem.

Acknowledgments We wish to thank Dr. Marthan Bester and two anonymous reviewers for their helpful comments on the manuscript. We are also grateful to Mr. Campbell McMillan for improvement of the English language in text. This work was funded by the Dirección Nacional del Antártico and the Agencia Nacional de Promoción Científica y Tecnológica (Grants: Picto No. 11559-36054). Our procedures conform with the Code of Ethics of Animal Experimentation in Antarctica. The permit for this work was granted by the Dirección Nacional del Antártico (Environmental Office), Argentina. This work is dedicated to the memory of Dr. Alejandro Carlini ("Alex").

\section{References}

Allcock AL (2005) On the confusion surrounding Pareledone charcoti (Joubin 1905) (Cephalopoda: Octopodidae): endemic radiation in the Southern Ocean. Zool J Linn Soc 143:75-108

Allcock AL, Strugnell JM, Prodöhl P, Piatkowski U, Vecchione M (2007) A new species of Pareledone (Cephalopoda: Octopodidae) from Antarctic Peninsula waters. Polar Biol 30:883-893

Allcock AL, Barrat I, Eléaume M, Linse K, Norman MD, Smith PJ, Steinke D, Stevens DW, Strugnell JM (2011) Cryptic speciation and the circumpolarity debate: a case study on endemic Southern Ocean octopuses using the COI barcode of life. Deep-Sea Res 58:242-249

Arnbom TA, Lunn NJ, Boyd IL, Barton T (1992) Aging live Antarctic fur seals and southern elephant seals. Mar Mamm Sci 8:37-43

Authier M, Delord K, Guinet C (2011) Population trends of female Elephant Seals breeding on the Courbet Peninsula, îles Kerguelen. Polar Biol 34:319-328 
Barrera-Oro E (2002) The role of fish in the Antarctic marine food web: differences between inshore and offshore waters in the southern Scotia Arc and west Antarctic Peninsula. Antarct Sci 14:293-309

Bester MN (1988) Marking and monitoring studies of the Kerguelen stock of southern elephant seals Mirounga leonina and their bearing on biological research in the Vestfold Hills. Hydrobiologia 165:269-277

Bigg MA, Fawcett I (1985) Two biases in diet determination of northern fur seal (Callorhinus ursinus). In: Beddington JR, Beverton RJH, Lavigne DM (eds) Marine mammals and fisheries. Allen \& Unwin, London, pp 284-291

Biuw M, Boehme L, Guinet C, Hindell MA, Costa DP, Charrassin J-B, Roquet F, Bailleul F, Meredith M, Thorpe S, Tremblay Y, McDonald BI, Park Y-H, Rintoul SR, Bindoff N, Goebel ME, Crocker DE, Lovell P, Nicholson J, Monks F, Fedak M (2007) Variations in behavior and condition of a Southern Ocean top predator in relation to in situ oceanographic conditions. Proc Natl Acad Sci USA 104:13705-13710

Bornemann H, Kreyscher S, Ramdohr S, Martin T, Carlini A, Sellmann L, Plotz J (2000) Southern elephant seal movements and Antarctic sea ice. Antarct Sci 12:3-15

Boyd IL, Walker TR, Poncet J (1996) Status of southern elephant seals in South Georgia. Antarct Sci 8:237-244

Bradshaw CJA, Hindell MA, Best NJ, Phillips KL, Wilson G, Nichols PD (2003) You are what you eat: describing the foraging ecology of southern elephant seals (Mirounga leonina) using blubber fatty acids. Proc R Soc Lond B 270:1283-1292

Brown DJ, Boyd IL, Cripps GC, Butler PJ (1999) Fatty acid signature analysis from the milk of Antarctic fur seals and Southern elephant seals from South Georgia: implications for diet determination. Mar Ecol Prog Ser 187:251-263

Burns JM (1999) The development of diving behavior in juvenile Weddell seals: pushing physiological limits in order to survive. Can J Zool 66:446-458

Campagna C, Lewis M (1992) Growth and distribution of a southern elephant seal colony. Mar Mamm Sci 8:387-396

Carlini AR, Marquez MEI, Daneri GA, Poljak S (1999) Mass changes during their annual cycle in females of southern elephant seals at King George Island. Polar Biol 21:234-239

Carlini AR, Daneri GA, Marquez MEI, Bornemann H, Panarello H, Casaux R, Ramdohr S, Plotz J (2005) Food consumption estimates of southern elephant seal females during their postbreeding aquatic phase at King George Island. Polar Biol 28:769-775

Carlini AR, Poljak S, Daneri GA, Márquez MEI, Negrete J (2006) The dynamics of male harem dominance in southern elephant seals (Mirounga leonina) at the South Shetland Islands. Polar Biol 29:796-805

CCAMLR (2008) Statistical bulletin, vol 20 (1998-2007). CCAMLR, Hobart

Chaigne A, Authier M, Richard P, Cherel Y, Guinet C (2013) Shift in foraging grounds and diet broadening during ontogeny in southern elephant seals from Kerguelen Islands. Mar Biol 160:977-986

Cherel Y, Ducatez S, Fontaine C, Richard P, Guinet C (2008) Stable isotopes reveal the trophic position and mesopelagic fish diet of female southern elephant seals breeding on Kerguelen Islands. Mar Ecol Prog Ser 370:239-247

Clarke MR (1986) A handbook for the identification of cephalopod beaks. Clarendon Press, Oxford

Clarke MR, MacLeod N (1982) Cephalopods in the diet of elephant seals at Signy Island, South Orkney Islands. Br Antarct Surv Bull 57:27-31

Collins MA, Rodhouse PGK (2006) Southern ocean cephalopods. Adv Mar Biol 50:191-265
Cortés E (1997) A critical review of methods of studying fish feeding based on analysis of stomach contents: application to elasmobranch fishes. Can J Fish Aquat Sci 54:726-738

Croxall JP, Prince PA, Ricketts C (1985) Relationships between prey life-cycles and the extent, nature and timing of seal and seabird predation in the Scotia Sea. In: Siegfried WR, Condy P, Laws RM (eds) Antarctic nutrient cycles and food webs. Springer, Berlin, pp 516-533

Daneri GA, Carlini AR (2002) Fish prey of southern elephant seals, Mirounga leonina, at King George Island. Polar Biol 25:739-743

Daneri GA, Carlini AR, Rodhouse PGK (2000) Cephalopod diet of the southern elephant seal, Mirounga leonina, at King George Island, South Shetland Islands. Antarct Sci 12:16-19

Daneri GA, Carlini AR, Harrington A (2005) The feeding habits of male southern elephant seals, Mirounga leonina, at King George Island, South Shetland Islands. In: Proceedings of the IX SCAR international biology symposium, Curitiba

Daneri GA, Carlini AR, Negri A, Allcock AL, Corbalán A (2012) Predation on cephalopods by Weddell seals, Leptonychotes weddellii, at Hope Bay, Antarctic Peninsula. Polar Biol 35:585-592

Dragon AC, Bar-Hen A, Monestiez P, Guinet C (2012) Horizontal and vertical movements as predictors of foraging success in a marine predator. Mar Ecol Prog Ser 447:243-257

Ducatez S, Dalloyau S, Richard P, Guinet C, Cherel Y (2008) Stable isotopes document winter trophic ecology and maternal investment of adult female southern elephant seals (Mirounga leonina) breeding at the Kerguelen Islands. Mar Biol 155:413-420

Field I, Hindell MA, Slip DJ, Michael KJ (2001) Foraging strategies of southern elephant seals (Mirounga leonina) in relation to frontal zones and water masses. Antarct Sci 13:371-379

Field IC, Bradshaw CJA, Burton HR, Sumner MD, Hindell MA (2005) Resource partitioning through oceanic segregation of foraging juvenile southern elephant seals. Oecologia 142:127-135

Field IA, Bradshaw CJA, van den Hoff J, Burton HR, Hindell MA (2007) Age-related shifts in the diet composition of southern elephant seals expand overall trophic niche. Mar Biol 150:1441-1452

Filippova JA, Pakhomov EA (1994) Young squid in the plankton of Prydz Bay, Antarctica. Antarct Sci 6:171-173

Fischer W, Hureau JC (1988) FAO species identification sheets for fisheries purposes. Southern Ocean (Fishing areas 48, 58 and 88 CCAMLR convention area), vol 1-2. CCAMLR, Rome

Gon O, Heemstra PC (1990) Fishes of the Southern Ocean, 1st edn. JLB Smith Institute, Grahamstown

Green K, Burton HR (1993) Comparison of the stomach contents of the Southern elephant seal, Mirounga leonina, at Macquarie and Heard Islands. Mar Mamm Sci 9:10-22

Green K, Williams R (1986) Observations on food remains in faeces of elephant, leopard and crabeater seals. Polar Biol 6:43-45

Groger J, Piatkowski U, Heinemann H (2000) Beak length analysis of the Southern Ocean squid Psychroteuthis glacialis (Cephalopoda: Psychroteuthidae) and its use for size and biomass estimation. Polar Biol 23:70-74

Harvey JT, Antonelis GA (1994) Biases associated with non-lethal methods of determining the diet of northern elephant seals. Mar Mamm Sci 10:178-187

Hecht T (1987) A guide to the otoliths of Southern Ocean fishes. S Afr J Antarct Res 17:1-87

Hindell MA, Slip DJ, Burton HR (1991) The diving behavior of adult male and female southern elephant seals, Mirounga leonina (Pinnipedia: Phocidae). Aust J Zool 39:595-619

Hindell MA, Slip DJ, Burton HR (1994) Possible causes of the decline of southern elephant seal populations in the southern Pacific and southern Indian Oceans. In: Le Boeuf BJ, Laws RM (eds) Elephant seals: population ecology, behavior, and physiology. University of California Press, Berkeley, pp 66-84 
Hubold G (1984) Spatial distribution of Pleuragramma antarcticum (Pisces: Nototheniidae) near the Filchner and Larson Ice Shelves (Weddell Sea/Antarctica). Polar Biol 3:231-236

Hubold G, Ekau W (1987) Midwater fish fauna of the Weddell Sea, Antarctica. In: Kullander SO, Fernholm B (eds) Proceedings of the fifth congress of European ichthyologists. Swedish Museum of Natural History, Stockholm, pp 391-396

Irvine LG, Hindell MA, Van den Hoff J, Burton HR (2000) The influence of body size on dive duration of underyearling southern elephant seals (Mirounga leonina). J Zool (Lond) 251:463-471

Jonker FC, Bester MN (1998) Seasonal movements and foraging areas adult southern female elephant seals, Mirounga leonina, from Marion Island. Antarct Sci 10:21-30

Kooyman GL, Castellini MA, Davis RW, Maue RA (1983) Aerobic dive limits in immature Weddell seals. J Comp Physiol 151:171-174

Kozlov AN (1995) A review of the trophic role of mesopelagic fish of the family Myctophidae in the Southern Ocean ecosystem. CCAMLR Sci 2:71-77

Laws RM (1956) The elephant seal (Mirounga leonina Linn). II. General, social and reproductive behaviour. Sci Rep Falkl Isl Depend Surv 13:1-88

Laws RM (1994) History and present status of the southern elephant seal populations. In: Le Boeuf BJ, Laws RM (eds) Elephant seals: population ecology, behaviour and physiology. University of California Press, Berkeley, pp 49-65

Le Boeuf BJ, Morris PA, Blackwell SB, Crocker DE, Costa DP (1996) Diving behavior of juvenile northern elephant seals. Can J Zool 74:1632-1644

Lu CC, Williams R (1994) Contribution to the biology of squid in the Prydz Bay region, Antarctica. Antarct Sci 6:223-229

McConnell BJ, Fedak MA (1996) Movements of southern elephant seals. Can J Zool 74:1485-1496

McIntyre T, Ansorge I, Bornemann H, Plötz J, Tosh C, Bester M (2011) Elephant seal dive behaviour is influenced by ocean temperature: implications for climate change impacts on an ocean predator. Mar Ecol Prog Ser 441:257-272

McMahon CR, Bester MN, Burton HR, Hindell MA, Bradshaw CJA (2005) Population status and trends of a wide-ranging marine mammal predator, the southern elephant seal: reexamining hypotheses to explain the decline. Mamm Rev 35:82-100

Mennucci JA, Negrete J, Juáres MA, Santos MM, Coria NR, Márquez ME (2012) Seasonal variation in the number of breeding females of Southern Elephant Seal, at 25 de Mayo/King George Island. XXXII SCAR and Open Science Conference. Portland, Oregón

Moore JK, Abbott MR, Richman JG (1999) Location and dynamics of the Antarctic Polar Front from satellite sea surface temperature data. J Geophys Res 104:3059-3073

Newland CB, Field IC, Nichols PD, Bradshaw CJA, Hindell MA (2009) Blubber fatty acid profiles indicate dietary resource partitioning between adult and juvenile southern elephant seals. Mar Ecol Prog Ser 384:303-312

Newland CB, Field IC, Cherel Y, Guinet C, Bradshaw CJA, McMahon CR, Hindell MA (2011) Diet of juvenile southern elephant seals reappraised by stable isotopes in whiskers. Mar Ecol Prog Ser 424:247-258

North AW (1996) Fish in the diet of Antarctic fur seals (Arctocephalus gazella) at South Georgia during winter and spring. Antarct Sci 8:155-160

Okutani T, Clarke M (1985) Identification key and species description for Antarctic squids. BIOMASS Handbook no 21

Piatkowski U, Vergani DF, Stanganelli ZB (2002) Changes in the cephalopod diet of southern elephant seal females at King George Island, during El Niño-La Niña events. J Mar Biol Assoc UK 82:913-916
Pinkas L, Oliphant MS, Iverson ILK (1971) Food habits of albacore, bluefin tuna and bonito in California waters. California Department of Fish and Game, Fish Bull 152:1-105

Pusch C, Hulley PA, Kock KH (2004) Community structure and feeding ecology of mesopelagic fishes in the slope waters of King George Island (South Shetland Islands, Antarctica). DeepSea Res I 51:1685-1708

Reeves RR, Stewart BS, Leatherwood S (1992) The Sierra Club handbook of seals and sirenians. Sierra Club Books, San Francisco

Reid K (1995) The diet of Antarctic fur seals, Arctocephalus gazella, during winter at South Georgia. Antarct Sci 7:241-249

Reid K (1996) A guide to the use of otoliths in the study of predators at South Georgia. British Antarctic Survey

Rodhouse PGK, Prince PA, Clarke MR, Murray AWA (1990) Cephalopod prey of the grey-headed albatross Diomedea chrysostoma. Mar Biol 104:353-362

Rodhouse PG, Arnbom TR, Fedak MA, Yeatman J, Murray AWA (1992) Cephalopod prey of the southern elephant seal, Mirounga leonina L. Can J Zool 70:1007-1015

SCAR (2006) Report of the 29th meeting of the SCAR Group of Specialists on seals. Hobart, Tasmania

Slip DJ (1995) The diet of southern elephant seals (Mirounga leonina) from Heard Island. Can J Zool 73:1519-1528

Slip DJ, Hindell MA, Burton HR (1994) Diving behavior of southern elephant seals from Macquarie Island: an overview. In: Le Boeuf BJ, Laws RM (eds) Elephant seals: population ecology, behavior, and physiology. University of California Press, Berkeley, pp 253-270

Tollit DJ, Steward M, Thompson PM, Pierce GJ, Santos MB, Hughes S (1997) Species and size differences in the digestion of otoliths and beaks; implications for estimates of pinniped diet composition. Can J Fish Aquat Sci 54:105-119

Tosh CA, Bornemann H, Ramdohr S, Schroder M, Martin T, Carlini AR, Plotz J, Bester MN (2009) Adult male southern elephant seals from King George Island utilize the Weddell Sea. Antarct Sci 21:113-121

Vacquié-Garcia J, Royer F, Dragon AC, Viviant M, Bailleul F, Guinet C (2012) Foraging in the darkness of the Southern Ocean: influence of Bioluminescence on a deep diving predator. PLoS ONE 7:e43565

Van den Hoff J (2004) A comparative study of the cephalopod prey of Patagonian toothfish (Dissostichus eleginoides) and southern elephant seals (Mirounga leonina) near Macquarie Island. Polar Biol 27:604-612

Van Den Hoff J, Burton H, Davies R (2003) Diet of male southern elephant seals (Mirounga leonina L.) hauled out at Vincennes Bay, East Antarctica. Polar Biol 26:27-31

Vergani DF, Spairani HJ (1980) Elefante marino I. Estudio del crecimiento durante la lactancia del elefante marino del sur, Mirounga leonina. Contribución del Instituto Antártico Argentino 270:93-118

Walters A, Lea MA, van den Hoff J, Field IC, Virtue P, Sokolov S, Pinkerton MH, Hindell MA (2014) Spatially explicit estimates of prey consumption reveal a new krill predator in the Southern Ocean. PLoS ONE 9:e86452

Williams R, McEldowney A (1990) A guide to the fish otoliths from waters off the Australian Antarctic Territory, Heard and Macquarie Island. ANARE Res 75:1-173

Xavier JC, Cherel Y (2009) Cephalopod beak guide for the Southern Ocean. British Antarctic Survey, Cambridge 